Удк: 502/504:339.924:061.1ЕС(091) «19»

DOI: 10.26661/zhv-2019-1-53-37

\title{
Environmental integration in the European Union
}

\section{T. Yu. Perga \\ State Institution "Institute of World History of NAS of Ukraine" pergatatiana@gmail.com}

Key words: EU, environmental integration, environmental policy, sustainable development

The process of environmental integration in the European Union has explored. The main stages of the formation of a Common EU policy on environmental protection have been identified. It has shown that it was caused by the emergence of the first environmental problems in the EU in 1960-1970's and their exacerbation. The development of this policy has been demonstrated on the example of the seven Environmental Action Programs (EAP). The main milestones of the formation of environmental integration have established. They are: the Single European Act (1986), the Maastricht Treaty (1992), the Amsterdam Treaty (1997), the Cardiff Process (since 1997). The peculiarity of the European environmental integration has revealed, in particular, the inclusion of the imperatives of sustainable development in the environmental policy and many directions of the domestic policy. It has concluded that the adoption of national strategies contributes to better coordination of sustainable development policies by integrating it into horizontal and vertical levels of the governance. The vertical and horizontal mechanisms of integration of sustainable development in the EU Member States have analyzed. It has been proved that the special feature of recent years was the establishment in some Member States the special structures responsible for the environmental integration, as well as taking into account environmental imperatives in the planning of financing their activities. It has concluded that environmental integration process has multi-level and multi-vector character although in different periods it had different speed and scale. However taking into account high priority of the environmental protection in the EU domestic and international policy it is worth waiting for further development of environmental integration in the European Union.

\section{Екологічна інтеграція в Європейському Союзі}

\section{T. Ю. Перга}

Інститут всесвітньої історії НАН України

Ключові слова: $€ C$, екологічна інтеграція, екологічна політика, сталий розвиток
Досліджено процес екологічної інтеграції в Європейському Союзі. Виявлено головні етапи формування спільної політики ЕС з охорони довкілля. Продемонстровано розвиток цієї політики у семи Програмах дій з охорони навколишнього середовища (ЕПД). Встановлено головні віхи формування екологічної інтеграції, серед яких Єдиний Європейський акт (1986 р.), Маастріхтський договір (1992р.), Амстердамський договір (1997р.), Кардифський процес. 3'ясовано особливість європейської екологічної інтеграції, зокрема це включення до екологічної політики і багатьох сфер внутрішньої політики завдань сталого розвитку. Проаналізовано вертикальні та горизонтальні механізми інтеграції сталого розвитку в країнах-членах ЄС. Доведено, що особливістю останніх років стало створення у державах-членах ЄС спеціальних структур, що відповідають за екологічну інтеграцію, а також врахування екологічних імперативів у процесі планування фінансування їхньої діяльності.
At the beginning of the XXI century, it is possible to state the effectiveness of the EU ecological policy comparing to the same policy of many other countries. One reason for this is the including of environmental considerations into other policies by the European Union and Member States which we define as the ecological integration. The investigation of the European experience in this context is relevant and useful for Ukraine which has chosen the way of European integration and tries to get close to the environmental policy and standards of the EU.

There are many gaps in the Ukrainian studies of 
the European environmental policy. At the moment, Ukrainian researchers have developed the following questions: analyses of issues of Common EU policies, different directions of the European integration processes (V. Voles, G. Voles, I. Hrytsiak, V. Kopiyka, V. Poselsky, T. Shynkarenko etc); European environmental protection policy and its legal basis (0. Bondar, M. Sansi, M. Mikievich, M. Petras, G. Ayres, L. Kohrsen, S. Bukowski, L. Mering, N. König-Vitkovska, J. Domenkin etc); issues of public administration in the field of environmental protection (K. Ananicheva, $E$. Alaev, I. Blechtsina, M. Brynchuk, 0. Gavrilenko, S. Yelkina, N. Kobetsky, V. Komarnytskyy, B. Krischenko, 0. Kolbasov, V. Kostytsky, L. Kozhushko, V. Kravtsiv, M. Myagchenko, Y. Oliynyk, K. Riabets, M. Khilko, T. Kutsenko, A. Nikiforov, N. Malysh, P. Fesyanov, S. Chistov etc.). The disadvantage of existing studies is the lack of analysis on the evolution of the European environmental policy in the context of integration processes. Meanwhile, on our opinion, environmental integration plays important role in the forming of the European common environmental policy, by develop it in "depth" and "breadth". Therefore, it is important to overcome this scientific gap, which is the aim of this article.

Compared to other politics, the EU common environmental policy is quite "young". It has passed through several stages. Neither Paris Treaty (1950) nor Rome Treaty (1957) directly granted the European Community power in the field of environmental protection. In the initial stages of the formation of the EU, the priorities were aspects of economic, political and military integration. During 1950-1960s EU activities only indirectly related to environmental protection which aimed to reach economic and social goals.

The formation of the Common environmental policy caused the emergence of the first environmental problems in the EU in the 1960-1970's and their further aggravation. It started with an ambitious program. After the first United Nations Conference on the Human Environment in Stockholm in 1972 and growing public and scientific concerns on the limits to growth, the European Commission has undertaken commitments implemented in the Environmental action plans (EAP). The first EAP was adopted in November 1973. It emphasized the need for a comprehensive assessment of the impacts of other policies, in an effort to avoid damaging activities [1]. The Second EAP (1977 - 1981) followed up the ideas of the first plan. Special attention received nature protection, particularly quality of water and air. These measures did not require significant political intervention; they were mostly solved by the adoption of directives and regulations of national character. On our opinion, the influence of integration tendencies on the formation of the Common environmental policy was rather weak due to lack of shared vision of needed environmental protection activities [2].

The Third EAP (1982 - 1986) and partially the Fourth EAP (1987 - 1992) reflected a significant change in policy approach, being much more closely related to the completion of the Internal Market than their predecessors. In the Third EAP a key driver for programming and activities became linkage between the internal market and environmental policies. The question of harmonizing the environmental emissions standards was put on the agenda. The plan also emphasized the economic and social benefits from environmental policies. Objects of waste avoidance, efficient resource use and integrated environmental technologies were included in the Third EAP [3].

The Fourth EAP demonstrated a further change in the approach to environmental policy. The Single European Act (1986) marked a more prominent role for environmental protection in EU policy-making, introducing the idea that it should be considered in all new Community legislation. The shortcomings of the earlier approaches to the common environmental policy also were recognized. The Fourth EAP began to implement a new "sectoral approach", focusing on the analysis of the impact of strategic economic sectors on the environment. This was an initial commitment for the strategic reorientation of environmental policies in the EU, which gradually took place in 1989 - 1994 [4].

Further development of this approach can be seen in the Fifth EAP (1992 - 1999). Significant impact on this caused the United Nations Conference on Environment and Development of 1992. Thus, key elements of the plan included implementation the ideas of sustainable development; using of market - based instruments and "sectoral approach", limit of old end-of-pipe approaches; involvement of civil society and local communities in the environmental policy. Therefore, the Fifth EAP tried to reorient environmental protection policy towards «ecological structural change» [5, p.86-88].

Existed Ukrainian studies have not analyzed the problems of the environmental integration in the EU. However, official documents show that new approach of the Community did not find sufficient support amongst Member States in the 1990s. As states report "Environmental policy integration in Europe. Administrative culture and practices" soon after the Rio de Janeiro conference several Member States decided to promote the new agenda focuses on the decentralization of environmental policies 
which contradicted the ambitious ideas of the Fifth EAP and goals of the Common European environmental policy. It slowed down the achievement of programs goals. The authors of this report even used the term "roll-back of environmental policies" [6, p.11-12]. This can be explained by the different national economic interests of the $\mathrm{EU}$ member states and the complexity of their coordination even in a common market. Therefore, from one hand, in the late 1990s EU implemented the «sustainability approach» and related initiatives and, from the other hand, attempts of deregulation and diffusion of competencies existed. After environmental issues were strengthened as a Community target in the Amsterdam Treaty from 1997 (article 6 of which states that «environmental protection requirements must be integrated into the definition and implementation of the Community policies... in particular with a view to promoting sustainable development») [7, p.58], the Commission launched an initiative for environmental policy integration, called the Cardiff Process. It was directed to integrate environmental considerations into practice by putting article 6 of the EC Treaty into practice.

In result, environmental policy integration and sustainable development became key elements of a complex architecture of many strategic documents. The Commission shifted from its previous top-down approach and its instrumental focus of environmental policy integration towards a broader and less committed approach. The sectoral groups of the European Council had to identify the key problems of their sectors, to determine objectives and to formulate activities in order to meet them [6].

The overall political agenda of the 6th EAP (2002-2012) was driven by the development concerns of new Member States, a new wave of deregulation connected with the debate on European Governance and the increasing relevance of economic considerations. Generally this plan created a framework of general principles and objectives, which were implemented in the thematic strategies on such key issues, as resources, recycling, soils, pesticides, urban and marine environment, clean air [8]. Besides, the Commission has changed its role from an initiator of legislation to a manager of policy processes. EU environmental policy was substantially expanded by the Treaties of Maastricht (1992) and Amsterdam (1997), which made sustainable development one of the EU's central objectives. Sustainable development became also a key part of the Europe 2020 strategy, which underpins whole EU policy regarding the single market. The Lisbon Treaty (2007) reiterated the objective of sustain- able development and in 2010, the EU renewed a number of environmental Directives to ensure they comply with the Lisbon Treaty.

The 7th EAP (2014-2020) which intends to give more long-term direction to the common European environmental policy by better implementation of legislation, better information using the improving the knowledge base, more and wiser investment for environment and climate policy includes also issue of full integration of environmental requirements and considerations into other policies [9].

A special feature of the ecological integration in the EU is also the inclusion of the sustainable development imperative in many areas of domestic policy as well as in the work of many structures. In addition, this example clearly demonstrates the essence of this process.

On the EU level, three strategies for sustainable development were adopted: in 2001, 2005, and 2010. The accession to the European Union in 2004 led to the synchronization of the policy of the post-socialist countries with the EU policy. In developing national policies, new EU members began to take into account the guidelines laid down in the European Union's strategies.

The analysis shows that the adoption of national strategies for sustainable development in the new EU Member States started yet during their associate membership. In particular, they were adopted: in Hungary - in 1999, in Poland - in 2000, in Slovakia - in 2001, in Latvia - in 2002, in Lithuania - in 2003, in the Czech Republic - in 2004 in Slovenia, and in Estonia in 2005, in Croatia - in 2009, in Bulgaria - in 2011.

All of them aimed at integrating the three components of sustainable development: economic, social and environmental, however some countries use a wider approach. For example, in Slovenia and Estonia, such strategy covered culture; in the Czech Republic - R \& D, education, European and international issues and good governance; in Lithuania - territorial development and development of cooperation. After joining the EU, new Member States adopted updated strategies of the sustainable development: Lithuania - in 2009, Czech Republic - in 2010, Slovenia - in 2014. Some countries took the EU 2020 strategy as a model and adopted the similar documents (Hungary - «National Framework for Sustainable Development 2012-2020»; Romania - «Romania 2013-20-30»; Latvia - «Latvia 2030»; where integrated the goals of sustainable development [10].

It should be emphasized that the adoption of national strategies promotes better coordination of sustainable development policies through its integration at the horizontal and vertical levels, as 
well as the activities of various sectors of society (public, private and academic circles, civil society), which becomes an important provision for the success in this area.

Vertical integration means the implementation of sustainable development at different levels of government (regional, national and local). The following mechanisms are common for all levels in the European Union:

1. Consultations, which usually take different forms. In EU-15 are popular workshops (Finland), round tables and discussions (Austria), meetings (Germany), dialogues (Denmark). Hungary develops online activities; in Estonia, the Joint Commission of the Ministerial Offices plays the role of a forum for multilevel co-operation. This mechanism facilitates the development of recommendations for the national strategies or requests for the activities of EU Member States.

2. Some EU Member States (Finland, Germany, and Switzerland) started the implementation of formal and informal mechanisms for strengthening cooperation and coordination which promotes better interaction between different levels of government.

3. Some countries (Hungary and Lithuania) have started a process of raising awareness, sharing experiences and information, although this mechanism, according to the research of Y. Pizano, K. Lepashits and J. Berger, is the least effective [10].

The integration of sustainable development into EU policies is also evident in the institutionalization of some mechanisms. The most widespread is the formation of councils, commissions or other bodies in EU countries (Switzerland, Germany, Latvia and Finland). For example, a National Development Board (NDC) was established in Latvia. It coordinates strategic planning between national and subnational levels. The members of this council headed by the prime minister are sub-national governmental bodies and regional planning institutions.

In some EU Member States, the policy of vertical integration is formalized in legal acts. Croatia has adopted the Environmental Protection Act (CO 11/07), which provides the responsibility for the implementation of sustainable development goals on various political levels, including national government, counties, cities and other relevant stakeholders.

Horizontal integration reflects the cooperation in implementation of sustainable development policies between different ministries and administrative bodies at the national level. As a rule, European countries develop different forms of inter-ministerial and inter-agency coordination. In this context they establish different bodies: the interagency group (Estonia), the commission (Belgium), the committee (Austrian Committee on Sustainable Development or the Committee of State Secretaries in Germany) the network (interagency network of the Secretariats in Finland).

Horizontal mechanisms can be divided into groups. The first is the interagency bodies of the highest, political level. Germany (the State Committee of Secretaries for Sustainable Development) should be mentioned as an example.

The second group of horizontal mechanisms consists of in the interagency bodies of the administrative level. Its participants are mainly representatives of national departments (ministries) under the leadership of the Ministry of Environmental Protection. Such kind of mechanisms were created: in Estonia the Commission on Sustainable Development (1996); in Romania - the National Center for Sustainable Development (1997); in Slovakia - the State Council on Sustainable Development (1999); in the Czech Republic - Government Council on Sustainable Development (2003); in Bulgaria - Interdepartmental Advisory Board on Sustainable Development (2006).

It is possible to identify a group of hybrid mechanisms which main feature is the participation (in the form of consultations) of the public, in particular, stakeholders such as NGOs, business and academia, civil society (Czech Republic, Hungary). So, in the Czech Republic, the Governmental Council for Sustainable Development is responsible for coordinating of the implementation of policies between central administrations on an interagency basis. Representatives of all ministries and stakeholders participate in various Council structures - committees and working groups [11].

Despite the various administrative styles and challenges that face environmental integration in Europe, environmental legislation, sustainable development strategies and planning provide a strong basis for development of this approach. During the process of the financing planning all state bodies in Member States have to take into account environmental issues. Netherlands demonstrates good example of budgetary planning processes to promote green and sustainable development goals. The mechanism of this is following. Each government department of the country within the preparing of financial statements for the coming year, have to explain how it will take into account the different dimensions of sustainable development. In Norway, all ministries must assess the expected environmental implications of their policy proposals and state these in their budgets after the consultations on these issues with the Ministry of the Environment. The state 
budget also specifically addresses the environment through a chapter listing the environmentally-relevant expenditures of all countries ministries.

The tendency of the last years is the founding of a special strategic units or other bodies to guide and support environmental policy integration. For example, the Finnish National Commission for Sustainable Development is chaired by the Premier Ministers and co-chaired by the Environment Minister. The Commission includes other ministers, as well as representatives of different actors of society. This Commission also acts as an advisory council. Germans State Secretaries' Committee for Sustainable Development (Green Cabinet) is chaired by the Federal Chancellery. It is responsible for interdepartmental management of the sustainable development process and regularly reports to the Federal Cabinet. There is a Council for Sustainable Development and advisory councils on environment, global change and land stewardship.

Other example is Norway. The National Committee for International Environmental Issues (NCIES) is chaired by the Ministry of Environment, and includes the Office of the Premier Minister, a number of ministries, private and non-governmental actors.
The NCIES plays the role of a discussion forum, advisory council and cross-sectoral coordination body. There is also a Committee on Sustainable Development which includes the Association of Local Councils, the Directors General of major trade unions and business associations, and the Norwegian Society for the sustainable development [12, p.17].

Thus, for several decades, the integration of environmental imperatives and the imperative of sustainable development into various areas of the domestic policy has been taking place in the EU. This process has multi-level and multi-vector character although in different periods the speed of its development and scale were different. However taking into account high priority of the environmental protection in the EU internal and international policy it is possible to prognosis the further development of environmental integration in the European Union. Ukraine should use this advanced European experience. It will help introduce more effective management approaches in environmental policy and solve numerous environmental problems. The perspective of further research is the development of concept of the environmental integration in Ukraine using the positive European experiences.

\section{Sources and literature:}

1. Popeanga V. Environmental Action Programmes in the European Union - evolution and specific. Annals of the "Constantin Brâncuși" University of Târgu Jiu, Letter and Social Science Series. 2013, № 3. P. 24-33. URL: http://www. utgjiu.ro/revista/lit/pdf/2013-03/3_Vasile\%20Popeanga\%20-\%20Environmental\%20action\%20programmes $\% 20$ in\%20the\%20european\%20union\%20-\%20evolutin\%20and\%20specific.pdf (Last accessed: 12.03.2019).

2. Weale A. Environmental rules and rule-making in the European Union. Journal of European Public Policy. 1996. Vol. 3, № 4. P. 594-611.

3. Hey C. EU Environmental Policies: A short history of the policy strategies. EU Environmental Policy Handbook. 2008. URL: https://pdfs.semanticscholar.org/445e/f8210932ca2b848b8d8b0d46072b592d97ae.pdf (Last accessed: 12.03.2019).

4. Towards Sustainability. The European Community Programme of policy and action in relation to the environment and sustainable development. Official Journal of the European Communities. 1993. № C 138. P.5-98. URL: http:// ec.europa.eu/environment/archives/action-programme/env-act5/pdf/5eap.pdf (Last accessed: 13.03.2019).

5. Knill C. Implementing EU Environmental Policy: New Directions and Old Problems. Manchester, 2000, 298 p.

6. Environmental policy integration in Europe. Administrative culture and practices / EEA Technical report. 2005. № 5. P.1-50.

7. Treaty of Amsterdam amending the Treaty on European Union, the Treaties Establishing the European Communities and Certain Related Acts. Luxembourg, 1997. 148 p.

8. Decision No 1600/2002/EC of the European Parliament and of the Council of 22 July 2002 laying down the Sixth Community Environment Action Programme. Official Journal. 2002. L 242, 10/09/2002 P. 0001 - 0015. URL:

https://eur-lex.europa.eu/legal-content/EN/ALL/?uri=CELEX:32002D1600 (Last accessed: 12.03.2019).

9. Decision No 1386/2013/EU of the European Parliament and of the Council of 20 November 2013 on a General Union Environment Action Programme to 2020 'Living well, within the limits of our planet'. Official Journal of the European Union. 2013. L 354/171. URL: https://eur-lex.europa.eu/legal-content/EN/TXT/?uri=CELEX:32013D1386 (Last accessed: 13.03.2019).

10. Meadowcroft J. National Sustainable Development Strategies: Features, Challenges and Reflexivity. European Environment. 2007. №17(3). P.152-163. Pisano U., Lepuschitz K., Berger G. National Sustainable Development Strategies in Europe 2013. ESDN Quarterly Report. 2013. 29 July. URL: http://www.sd-network.eu/?k=quarterly\%20 reports\&s=archive (Last accessed: 13.03.2019).

11. Steurer R., Martinuzzi A. Toward a New Pattern of Strategy Formation in the Public Sector: First Experiences with National Strategies for Sustainable Development in Europe. Environment and Planning: Government and Policy. 2005. № 23(3). P.455-472.

12. Scheuer S. EU Environmental Policy Handbook. A Critical Analysis of EU Environmental Legislation. EU Environmental Policy Handbook. 343 p. 